\title{
Glucagon-Like Peptide-1 Versus Somatostatin Receptor Targeting Reveals 2 Distinct Forms of Malignant Insulinomas
}

\author{
Damian Wild ${ }^{* 1,2}$, Emanuel Christ*3, Martyn E. Caplin ${ }^{4}$, Tom R. Kurzawinski ${ }^{5}$, Flavio Forrer ${ }^{6}$, Michael Brändle ${ }^{7}$, \\ Jochen Seufert ${ }^{8}$, Wolfgang A. Weber ${ }^{2}$, Jamshed Bomanji ${ }^{1}$, Aurel Perren ${ }^{9}$, Peter J. Ell ${ }^{1}$, and Jean Claude Reubi ${ }^{9}$ \\ ${ }^{1}$ Institute of Nuclear Medicine, University College Hospital, London, United Kingdom; ${ }^{2}$ Department of Nuclear Medicine, University \\ Hospital Freiburg, Freiburg, Germany; ${ }^{3}$ Divisions of Endocrinology, Diabetology, and Clinical Nutrition, Inselspital, University \\ Hospital of Berne, Berne, Switzerland; ${ }^{4}$ Neuroendocrine Tumor Unit, Royal Free Hospital, London, United Kingdom; ${ }^{5}$ Centre of \\ Endocrine Surgery, University College Hospital, London, United Kingdom; ${ }^{6}$ Institute of Nuclear Medicine, University Hospital Basel, \\ Basel, Switzerland; ${ }^{7}$ Divisions of Endocrinology, Diabetes, and Osteology, Kantonsspital St. Gallen, St. Gallen, Switzerland; \\ ${ }^{8}$ Division of Endocrinology and Diabetology, University Hospital Freiburg, Freiburg, Germany; and ${ }^{9}$ Institute of Pathology, \\ University of Berne, Berne, Switzerland
}

\begin{abstract}
Glucagon-like peptide-1 (GLP-1) receptor imaging is superior to somatostatin receptor subtype 2 (sst $)_{2}$ imaging in localizing benign insulinomas. Here, the role of GLP-1 and $s_{2} t_{2}$ receptor imaging in the management of malignant insulinoma patients was investigated. Methods: Eleven patients with malignant insulinoma were prospectively included. ${ }^{111}$ In-[Lys ${ }^{40}$ (Ahx-diethylenetriaminepentaacetic acid [DTPA]) $\mathrm{NH}_{2}$ ] -exendin-4 SPECT/CT, ${ }^{68} \mathrm{Ga}$ - DOTATATE PET/CT, and in vitro receptor autoradiography were performed to assess the receptor status and to evaluate the detection rate. Results: GLP-1 receptor targeting was positive in 4 of 11 patients, and $s t_{2}$ receptor expression was positive in 8 of 11 . In only 1 patient were both receptors expressed. In 1 patient, GLP-1 receptor imaging was the only method that successfully localized the primary tumor in the pancreas. In 3 patients with $\mathrm{sst}_{2}$-expressing tumors, DOTATATE radiotherapy was effectively applied. Conclusion: As opposed to benign insulinomas, malignant insulinomas often lack GLP-1 receptors. Conversely, malignant insulinomas often express $\mathbf{s s t}_{2}$, which can be targeted therapeutically.
\end{abstract}

Key Words: insulinoma; glucagon-like peptide-1 receptor targeting; somatostatin receptor subtype 2 targeting; peptide receptor radionuclide therapy

J Nucl Med 2011; 52:1073-1078

DOI: 10.2967/jnumed.110.085142

\section{$\mathbf{I}$} cidence of 0.4 per 100,000 people per year, arising from $\beta$-cells located in the islets of Langerhans (1). Insulinomas are usually benign but can be malignant in about $5 \%-15 \%$ of patients $(2,3)$.

Received Nov. 8, 2010; revision accepted Mar. 16, 2011.

For correspondence or reprints contact: Jean Claude Reubi, Division of Cell Biology and Experimental Cancer Research, Institute of Pathology, University of Berne, P.O. Box 62, Murtenstrasse 31, $\mathrm{CH}-3010$ Berne, Switzerland.

E-mail: reubi@pathology.unibe.ch

${ }^{*}$ Contributed equally to this work.

COPYRIGHT @ 2011 by the Society of Nuclear Medicine, Inc.
Insulinomas can become life-threatening if they cannot be removed surgically. In cases of malignant insulinoma, complete resection of all tumors is difficult and prognosis remains relatively poor, with a 5-y survival of $55.6 \%$ and 10 -y survival of $29 \%(2,4,5)$. Most of these patients have lymph node or liver metastases, and only rarely is there involvement of other sites such as bone. Accurate assessment of the extent of the disease is important, especially because preoperative localization of all lesions facilitates surgery $(6,7)$.

Recently, in vitro and in vivo studies have shown that glucagon-like peptide-1 (GLP-1) receptors are expressed in high density in almost all benign insulinomas (8). Consequently, GLP-1 receptor-specific radioligands have been developed and evaluated in animal models $(9,10)$ and in humans (11-13). Treatment studies in an animal tumor model using therapeutic doses of radiolabeled GLP-1 receptor agonist have shown the potential of GLP-1 receptor targeting as a therapeutic approach (14). Although therapeutic targeting of somatostatin receptor subtype $2\left(\mathrm{sst}_{2}\right)$ is an established method to treat patients with gastroenteropancreatic neuroendocrine tumors (15), the use of sst $_{2}$ receptor-targeted radiotherapy has been only anecdotal in malignant insulinomas $(15,16)$.

Thus, establishing the incidence and density of peptide receptor status in vivo in patients with malignant insulinomas should improve the assessment of the extent of disease and allow the formulation of a targeted therapeutic approach. However, neither the incidence nor the density of GLP-1 and sst $_{2}$ receptors is known in malignant insulinomas.

Therefore, we aimed at prospectively evaluating GLP-1 and $\mathrm{sst}_{2}$ receptor status in vitro or in vivo in 11 patients with clinical and biochemical evidence of endogenous hyperinsulinemic hypoglycemia and radiologic features of malignant insulinoma.

\section{MATERIALS AND METHODS}

\section{Patients and Study Design}

Patients with biochemical or clinical evidence for endogenous hyperinsulinemic hypoglycemia and CT findings suggestive of 
malignancy were eligible for this study. The total cohort consisted of 11 patients. Eight consecutive patients ( 4 women and 4 men) were prospectively recruited at 3 tertiary referral centers (University College Hospital London, University Hospital Basel, and University Hospital Freiburg). All patients underwent GLP-1 receptor imaging; additional $\mathrm{sst}_{2}$ receptor imaging was performed in 6 of these patients. GLP-1 receptor SPECT/CT scans (radiotracer, ${ }^{111}$ In-labeled [Lys ${ }^{40}\left(\right.$ Ahx-DTPA) $\mathrm{NH}_{2}$ ]-exendin-4, where DTPA is diethylenetriaminepentaacetic acid) and $\mathrm{sst}_{2}$ receptor PET/CT scans (radiotracer, ${ }^{68} \mathrm{Ga}$-DOTATATE) were obtained at the 3 centers using identical labeling and imaging protocols. In 4 patients (patients 1, 2, 5, and 6), fresh-frozen tumor tissue was available for quantitative assessment of GLP-1 and $\mathrm{sst}_{2}$ receptor density by in vitro receptor autoradiography $(17,18)$. In 3 additional patients (patients 8, 9, and 11), the GLP-1 and $\mathrm{sst}_{2}$ receptor status was evaluated by in vitro autoradiography only. The diagnosis was confirmed by histologic assessment of tumor samples in all patients.

The study was approved by the local institutional review board of each participating institution, and written informed consent was obtained in accordance with provisions of the Declaration of Helsinki.

\section{Synthesis and Radiolabeling of DTPA-Exendin-4 and DOTATATE}

DTPA-exendin-4 (10) and DOTATATE were custom-synthesized by Peptide Specialty Laboratories and Bachem, respectively.

For radiolabeling of DTPA-exendin-4 with ${ }^{111} \mathrm{InCl}_{3}$, an aliquot of approximately $50 \mu \mathrm{L}(20 \mu \mathrm{g})$ of DTPA-exendin- 4 was dissolved in $400 \mu \mathrm{L}$ of ammonium acetate buffer ( $0.2 \mathrm{M}, \mathrm{pH} 5.0)$, incubated with approximately $190 \mathrm{MBq}$ of ${ }^{111} \mathrm{InCl}_{3}$ (Mallinckrodt) at $90^{\circ} \mathrm{C}$ for $10 \mathrm{~min}$, and then subjected to quality control by analytic high-performance liquid chromatography (10). The labeling yield of ${ }^{111}$ In-DTPAexendin-4 was greater than $98 \%$ at a specific activity of 90 $\mathrm{GBq} / \mu \mathrm{mol}$ and a radiochemical purity of about $92 \%$.

Approximately $50 \mu \mathrm{g}$ of DOTATATE was radiolabeled with 600-1,200 MBq of ${ }^{68} \mathrm{Ga}$ with fully automated equipment from Eckert \& Ziegler as described before (19). The labeling yield and radiochemical purity of ${ }^{68} \mathrm{Ga}$-DOTATATE was greater than $97 \%$ at a specific activity of $17-34 \mathrm{GBq} / \mu \mathrm{mol}$.

\section{Imaging and Analysis of Tumor Samples}

In all patients, high-speed helical CT scans of the abdomen were obtained less than $6 \mathrm{wk}$ before receptor imaging using a dual-phase, thin-section (0.5-mm collimation) imaging protocol. Usually, $150 \mathrm{~mL}$ of nonionic contrast medium were administrated at $4 \mathrm{~mL} / \mathrm{s}$, with scan delays of approximately $30 \mathrm{~s}$ for the arterial phase and $70 \mathrm{~s}$ for the portal phase. Scanning was performed at $120 \mathrm{kV}$ and $100-300 \mathrm{~mA}$.

GLP-1 receptor total-body and SPECT/CT scans were acquired at $4 \mathrm{~h}$ and between 2 and $4 \mathrm{~d}$ after intravenous injection of $10 \pm 2 \mu \mathrm{g}$ (108-136 MBq) of ${ }^{111}$ In-DTPA-exendin-4. Imaging was performed with a combined SPECT/CT unit (Symbia T2 [Siemens], Infinia Hawkeye [GE Healthcare], or Bright View XCT [Philips]) equipped with a medium-energy, parallel-hole collimator (12). Blood samples were taken to measure blood glucose levels just before and at 15, 40, $60,120,180$, and 240 min after injection of ${ }^{111}$ In-DTPA-exendin-4.

$\mathrm{sst}_{2}$ receptor scans were obtained at $1 \mathrm{~h}$ after intravenous injection of $28 \pm 8 \mu \mathrm{g}(149-172 \mathrm{MBq})$ of ${ }^{68} \mathrm{Ga}$-DOTATATE. Imaging was performed with a combined PET/CT unit (Discovery ST16 [GE Healthcare] Gemini TF64 [Philips]) using a standard protocol (19). Before imaging, patients were asked to stop treatment with long- and short-acting somatostatin analogs.
CT scans were evaluated by experienced radiologists. Two nuclear medicine physicians independently assessed GLP-1 and $\mathrm{sst}_{2}$ receptor scans. The physicians were unaware of patients' identities, type of scan, or results of other imaging modalities. Afterward, lesion-by-lesion analysis was performed for all tumor foci. Concordant findings on receptor imaging and CT were interpreted as a tumor lesion. In the case of discrepancies between receptor imaging and CT, further evaluation was performed either by histologic assessment or follow-up imaging studies.

\section{RESULTS}

\section{GLP-1 and sst Receptor Status in Patients with Malignant Insulinoma}

Table 1 summarizes patient characteristics and biochemical evaluation at recruitment.

GLP-1 and $s t_{2}$ receptor imaging or in vitro receptor autoradiography of resected tumor samples was performed to test the GLP-1 and sst receptor status in malignant insulinoma (Table 2). GLP-1 receptors were expressed in the tumors of 4 patients $(36 \%)$, whereas $\mathrm{sst}_{2}$ receptors were found in the tumors of 8 patients $(73 \%)$. Importantly, only patient 1 expressed both receptors in the primary tumor and 1 locoregional lymph node metastasis, indicating similar receptor biology in the primary tumor and the single metastasis. All other patients showed overexpression of only 1 type of receptor (Table 2; Figs. 1 and 2). Moreover, GLP-1 receptor imaging detected all tumor lesions in GLP-1 receptor-positive tumors $(16 / 16)$, whereas sst $_{2}$ receptor imaging picked up all tumor lesions in $\mathrm{sst}_{2}$ receptor-positive tumors (35/35), resulting in a sensitivity of $100 \%$ when the 2 imaging methods were combined (Supplemental Table 1; supplemental materials are available online only at http:// jnm.snmjournals.org). CT, by contrast, identified 42 of 51 tumor lesions (82\%). In patients for whom both in vitro autoradiography and imaging studies were performed, an excellent correlation was found between in vitro and in vivo studies (Table 2; Figs. 1 and 2).

\section{Comparison of Biochemical Results and Peptide Receptor Expression}

About 40 min after the injection of ${ }^{111}$ In-DTPA-exendin$4(10 \pm 2 \mu \mathrm{g})$, blood sugar dropped by $1.1-3.3 \mathrm{mmol} / \mathrm{L}$ in patients with GLP-1 receptor-positive malignant insulinoma and by $0.5-0.6 \mathrm{mmol} / \mathrm{L}$ in patients with GLP-1 receptornegative malignant insulinoma (Table 2). No further side effects were observed.

Biochemical results at the end of the fasting test showed a tendency for lower insulin concentrations in patients with GLP-1 receptor-positive and $\mathrm{sst}_{2}$ receptor-negative tumors (3.0-80 mU/L) than in those with $\mathrm{sst}_{2}$ receptor-positive and GLP-1 receptor-negative tumors (20-143 mU/L) (Table 1).

\section{Clinical Course After Imaging}

Treatments and clinical course after imaging are summarized in Table 1. Four patients (patients 1, 5, 10, and 11) with limited disease (locoregional lymph node metastases or single liver lesion) were treated with curative-intent surgery. 
TABLE 1

Clinical Characteristics and Biochemical Evaluation of 11 Patients with Hypoglycemic Episodes and CT Findings Suggesting Malignant Insulinoma

\begin{tabular}{|c|c|c|c|c|c|c|c|c|c|}
\hline \multirow[b]{2}{*}{ Patient no. } & \multicolumn{3}{|c|}{$\begin{array}{c}\text { Clinical } \\
\text { characteristic }\end{array}$} & \multicolumn{4}{|c|}{$\begin{array}{l}\text { Biochemical evaluation } \\
\text { at end-of-fasting test }\end{array}$} & \multicolumn{2}{|c|}{ Clinical course after imaging } \\
\hline & $\begin{array}{l}\text { Age } \\
\text { (y) }\end{array}$ & Sex & $\begin{array}{c}\text { First } \\
\text { symptoms } \\
\left(\mathrm{mo}^{\dagger}\right)\end{array}$ & $\begin{array}{c}\text { Duration } \\
\text { of } \\
\text { fasting (h) }\end{array}$ & $\begin{array}{l}\text { Glucose } \\
\text { (mmol/L) }\end{array}$ & $\begin{array}{l}\text { C-peptide } \\
\text { (nmol/L) }\end{array}$ & $\begin{array}{l}\text { Insulin } \\
(\mathrm{mU} / \mathrm{L})\end{array}$ & $\begin{array}{c}\text { Treatment } \\
\text { after } \\
\text { imaging }\end{array}$ & $\begin{array}{l}\text { Remission }{ }^{\ddagger} \\
\text { status }\end{array}$ \\
\hline 1 & 62 & $\mathrm{M}$ & 1 & 20 & 1.9 & 0.44 & 3.0 & TE & Complete response \\
\hline 2 & 72 & $\mathrm{M}$ & 36 & 72 & 2.6 & 1.1 & 16 & DS & Partial response \\
\hline 3 & 54 & $\mathrm{~F}$ & 24 & 72 & 1.4 & 2.1 & 31 & PRRT & Partial response \\
\hline 4 & 48 & $\mathrm{~F}$ & 36 & 72 & 1.9 & 0.83 & 78 & PRRT & Persistent disease \\
\hline 5 & 53 & $\mathrm{M}$ & 6 & 14 & 1.8 & 2.0 & 143 & TE & Complete response \\
\hline 6 & 66 & $\mathrm{~F}$ & 5 & Not done & Not done & Not done & Not done & $\begin{array}{c}\mathrm{DP}+\mathrm{DS}+ \\
\mathrm{PRRT}\end{array}$ & $\begin{array}{l}\text { Partial } \\
\text { response }\end{array}$ \\
\hline 7 & 74 & $M$ & 1 & 72 & 2.3 & 0.43 & 7.0 & none & Persistent disease \\
\hline 8 & 68 & M & 9 & Not done & Not done & Not done & Not done & TE + Chemotherapy & Persistent disease \\
\hline 9 & 68 & $\mathrm{M}$ & 8 & 10 & 1.6 & 6.0 & 34.9 & TE & Persistent disease \\
\hline 10 & 78 & $\mathrm{~F}$ & 1 & 12 & 2.5 & 3.3 & 80 & TE & Not available§ \\
\hline 11 & 55 & $\mathrm{M}$ & 3 & 4 & 2.3 & 0.79 & 20 & DP & Complete response \\
\hline
\end{tabular}

*In 9 of 11 patients, fasting test was performed. Patient 6 presented with confusion and unconsciousness due to hypoglycemia; fasting test was not performed, but CT scans revealed liver lesions suggestive of malignancy.

${ }^{\dagger}$ Eight patients $(1,5,6,7,8,9,10$, and 11) who had neuroglycopenic symptoms less than 10 mo before recruitment did not receive specific medical therapy. Remaining 3 patients had neuroglycopenic symptoms for 24-36 mo before recruitment. They were treated individually with surgery, diazoxide, somatostatin analogs, and PRRT.

${ }^{\ddagger}$ Remission status at termination of study.

$\S$ Multimorbid patient who died of liver failure shortly after surgery.

$\mathrm{TE}=$ tumor enucleation or whipple surgery; DS = debulking surgery; DP = distal pancreatectomy.

Three of these patients were tumor free at the end of the study. In patient 1, GLP-1 receptor imaging was the only diagnostic method that could successfully localize the insulinoma in the pancreas and was therefore a decisive factor for patient management. Two patients with extensive disease (patients 2 and 6) received aggressive debulking surgery, and 3 patients (patients 3,4 , and 6 ) with positive ${ }^{68} \mathrm{Ga}$-DOTATATE PET findings were treated with 1-3 cycles of peptide receptor radionuclide therapy (PRRT) using ${ }^{90}$ Y-DOTATATE or ${ }^{177} \mathrm{Lu}-$ DOTATATE to control hypoglycemia and tumor growth. In patients 3 and 6, a partial response and normalization of blood glucose were achieved after treatment with ${ }^{90}$ Y-DOTATATE and ${ }^{177}$ Lu-DOTATATE, and patient 4 showed stable disease until termination of the study.

\section{DISCUSSION}

This is the first report, to our knowledge, that evaluates GLP-1 and sst $_{2}$ receptor targeting and status in vitro or in vivo in patients with malignant insulinoma. The main findings of this study are that malignant insulinomas do not always express GLP- 1 receptor, express sst $_{2}$ receptors more often than GLP-1 receptor, and always express 1 of the 2 receptors.

The present study shows that, in contrast to benign insulinomas $(8,12)$, only a low percentage of the malignant insulinomas (36\%) expressed GLP-1 receptors. However, somatostatin receptor scintigraphy, reported previously to have a low detection rate of less than $20 \%$ in benign insulinomas (20), was positive in $73 \%$ of malignant insulinomas in the present study. Concomitant GLP-1 and sst $_{2}$ receptor expression was discovered in only 1 patient. Importantly, all tumors in all patients could be localized with the combination of the 2 peptide receptor imaging methods.

The results obtained with GLP- 1 and sst $_{2}$ receptor targeting significantly affected clinical management and outcome in 4 of the recruited patients. Indeed, knowing that a given tumor expresses $s t_{2}$ receptor makes it a potential candidate for targeted radiotherapy with somatostatin analogs. The 3 patients with positive $s_{2} t_{2}$ receptor scan findings and progressive disease were treated with ${ }^{177} \mathrm{Lu}$-DOTATATE or ${ }^{90}$ Y-DOTATATE (PRRT). In 2 of these patients (patients 3 and 6), a partial response and normalization of blood glucose were achieved shortly after treatment. The third patient (patient 4) showed no further progression until the end of the study. In 1 patient, GLP-1 receptor scans correctly localized the insulinoma in the pancreas, whereas $\mathrm{CT}$ and MRI scans showed evidence for liver and lymph node metastases but were unable to localize the primary tumor. The patient was referred for surgery on the basis of the GLP-1 receptor scan findings and remained tumor-free until the end of the study.

Although it was not possible, for logistic reasons, to perform in vitro and in vivo assessment of GLP-1 and $\mathrm{sst}_{2}$ receptor status in all patients, our data indicate an excellent 


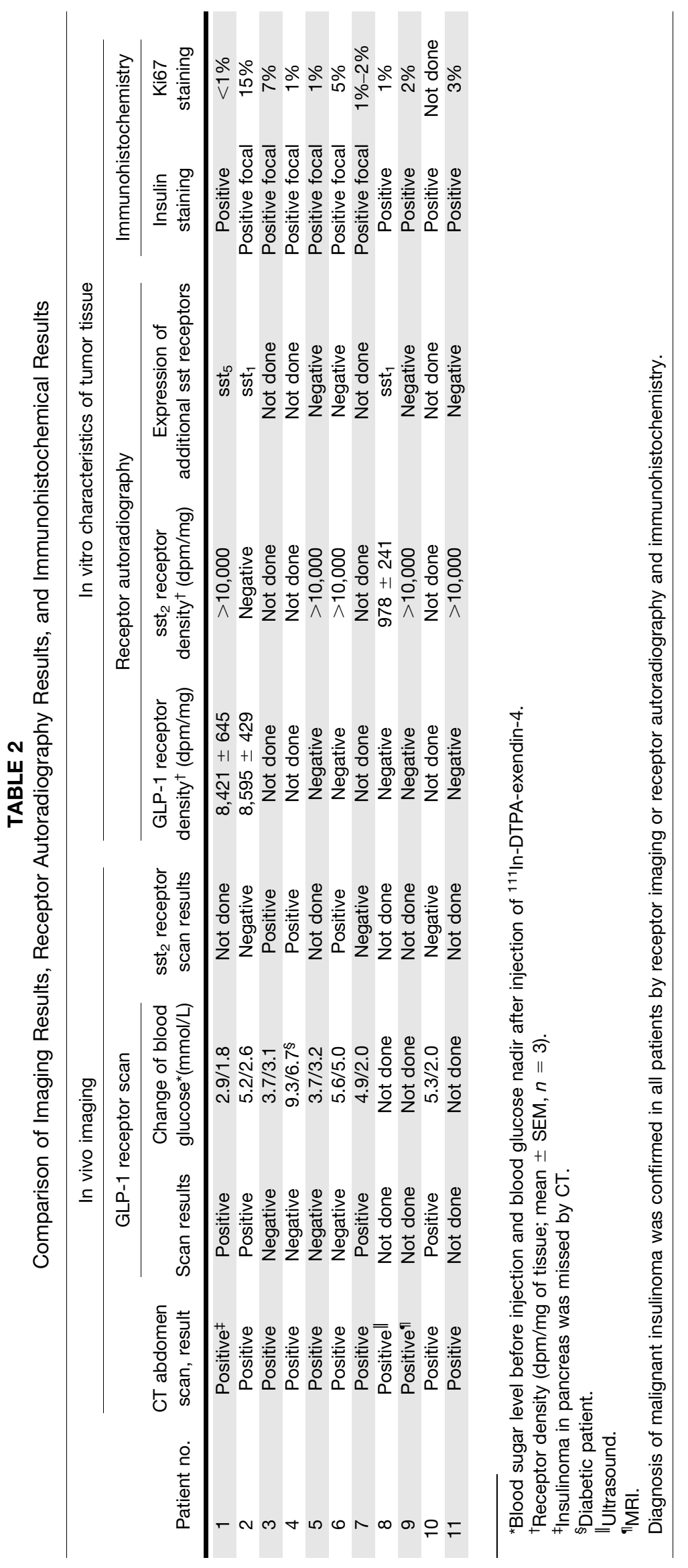

1076 The Journal of Nuclear Medicine • Vol. 52 • No. 7 • July 2011 

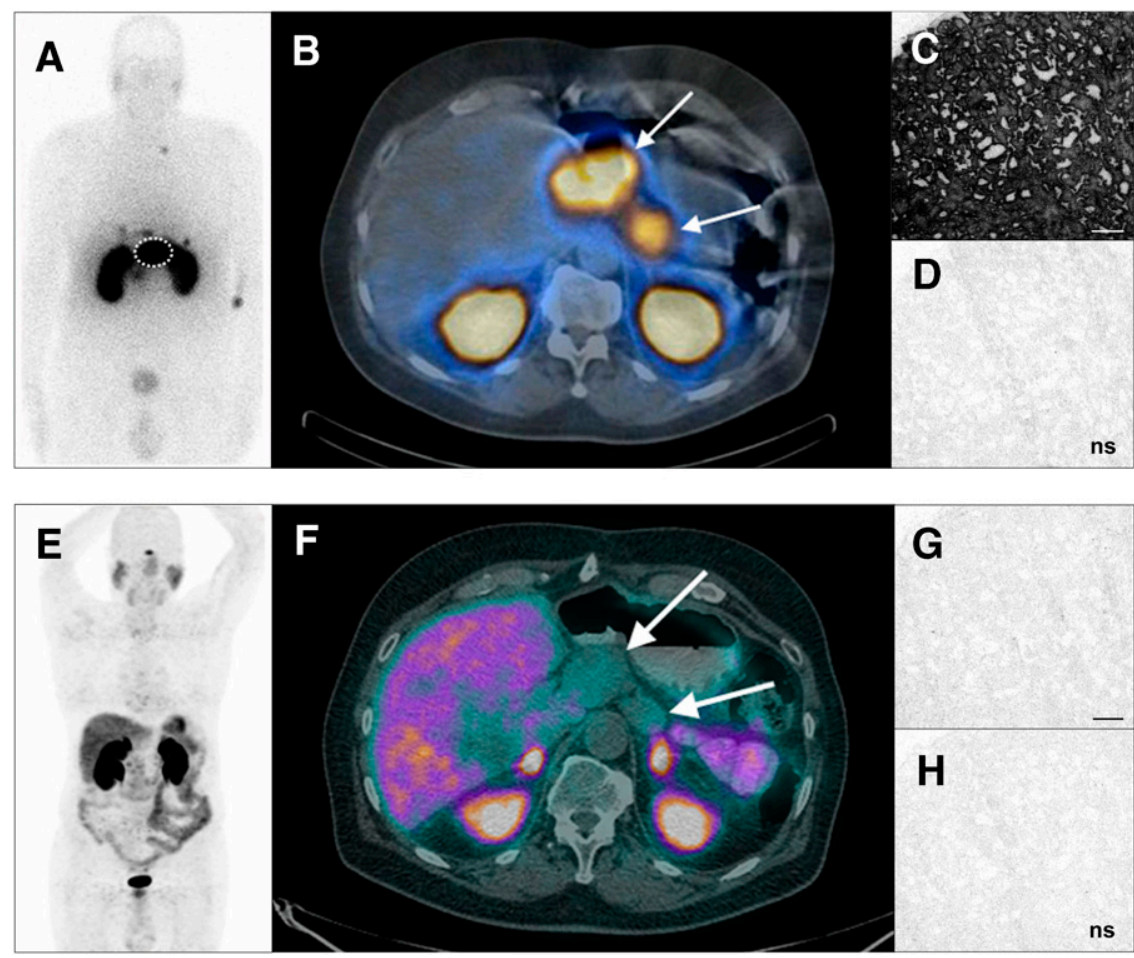

FIGURE 1. Example of GLP-1 receptorpositive and $\mathrm{sst}_{2}$ receptor-negative malignant insulinoma (patient 2). GLP-1 receptor scintigraphy (A) and SPECT/CT (B) were performed $4 \mathrm{~h}$ after injection of ${ }^{111} \mathrm{In}$ DTPA-exendin-4 (109 MBq), and sst ${ }_{2}$ receptor PET/CT (E and F) was performed $1 \mathrm{~h}$ after injection of ${ }^{68} \mathrm{Ga}$-DOTATATE (149 $\mathrm{MBq})$. Tumor tissue samples from same patient were used for in vitro GLP-1 (C and $D)$ and $s s t_{2}$ receptor ( $G$ and $H$ ) quantification. There is focal ${ }^{111}$ In-DTPA-exendin-4 uptake in 2 liver lesions, 1 cardiophrenic lesion, 1 left retroclavicular lymph node, and 1 retrosternal lymph node (A). Moreover, dotted circle in $A$ and arrows in $B$ show 2 large ${ }^{111}$ In-DTPA-exendin-4-avid lymph nodes adjacent to stomach. sst $_{2}$ receptor whole-body PET (E) shows normal ${ }^{68} \mathrm{Ga}-$ DOTATATE distribution even in large lymph nodes adjacent to stomach (arrows, F). There is excellent correlation between peptide receptor imaging and in vitro receptor quantification: autoradiograms show strongly positive specific binding of ${ }^{125}$ GLP-1 (7-36) amide in whole tumor (C), whereas ${ }^{125} \mathrm{I}-\left[\mathrm{Tyr}^{3}\right]$-octreotide shows only nonspecific binding (G). Autoradiograms show nonspecific binding of ${ }^{125}$ I-GLP-1 (7-36) amide (D) and ${ }^{125}$ I-[Tyr $\left.{ }^{3}\right]$-octreotide (H) in presence of $100 \mathrm{nM}$ GLP-1 (7-36) amide and $100 \mathrm{nM}$ octreotide, respectively. Bar $=1 \mathrm{~mm}$. correlation between in vivo and in vitro receptor data. The in vitro data indicate that there is an absence of the gray zone of mild to moderate receptor expression that could make in vivo assessment of receptor expression by PET and SPECT challenging. All tumors studied by autoradiography either demonstrated high density receptor expression or were completely negative. Therefore, the in vitro and in vivo data can be used interchangeably.
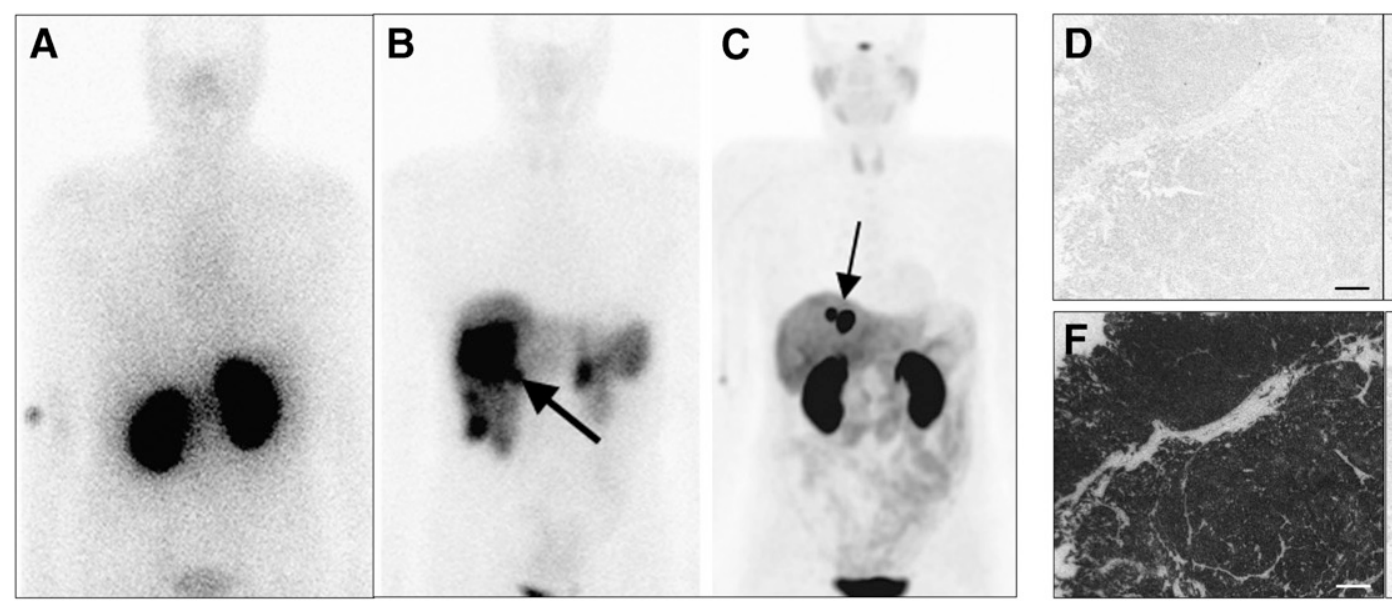

E

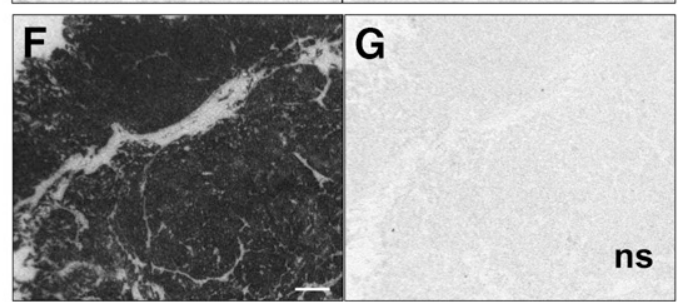

FIGURE 2. Example of GLP-1 receptor-negative and $s_{2} t_{2}$ receptor-positive malignant insulinoma (patient 6). Baseline GLP-1 receptor (A) and $\mathrm{sst}_{2}$ receptor scintigraphy (B) were performed $4 \mathrm{~h}$ after injection of ${ }^{111} \mathrm{In}$-DTPA-exendin-4 (124 MBq) and $99 \mathrm{mTc}$-tektrotyd (669 MBq), and posttreatment $\mathrm{sst}_{2}$ receptor PET (C) was performed $1 \mathrm{~h}$ after injection of ${ }^{68} \mathrm{Ga}$-DOTATATE (165 MBq). Tumor tissue samples from same patient were used for in vitro GLP-1 ( $\mathrm{D}$ and $\mathrm{E}$ ) and $\mathrm{sst}_{2}$ receptor ( $\mathrm{F}$ and $\left.\mathrm{G}\right)$ quantification. $\mathrm{sst}_{2}$ receptor scintigraphy shows intense ${ }^{99 m T c-}$ tektrotyd uptake in tail of pancreas and in multiple liver lesions (B). Arrow shows large 99mTc-tektrotyd-avid lesion in right liver lobe (B). GLP1 receptor whole-body scan shows normal ${ }^{111}$ In-DTPA-exendin-4 distribution, even in large liver lesion (A). After distal pancreatectomy, right hemihepatectomy, and PRRT good partial remission was achieved, with residual disease in only 2 liver lesions, with maximal diameter of $1.3 \mathrm{~cm}$ (arrow, C). Correlation is excellent between peptide receptor imaging and in vitro receptor quantification: autoradiograms show strongly positive specific binding of ${ }^{125} \mathrm{I}-\left[\mathrm{Tyr}^{3}\right]$-octreotide in whole tumor (F), whereas ${ }^{125} \mathrm{I}-\mathrm{GLP}-1$ (7-36) amide shows only nonspecific binding (D). Autoradiograms show nonspecific binding of ${ }^{125} \mathrm{I}-\mathrm{GLP}-1$ (7-36) amide (E) and ${ }^{125} \mathrm{I}-\left[\mathrm{Tyr} \mathrm{r}^{3}\right]$-octreotide (G) in presence of $100 \mathrm{nM}$ GLP-1 (7-36) amide and $100 \mathrm{nM}$ octreotide, respectively. Bar $=1 \mathrm{~mm}$. 


\section{CONCLUSION}

Our data indicate that, in contrast to benign insulinomas, malignant insulinomas often lack GLP-1 receptors but express sst $_{2}$ receptors more often. This observation is clinically relevant for 2 reasons. First, if a malignant insulinoma is suspected using biochemical investigations and conventional imaging, $\mathrm{sst}_{2}$ receptor imaging can be recommended for presurgical staging and potentially PRRT. Second, a scan negative for GLP-1 receptors may potentially indicate malignant insulinoma.

\section{DISCLOSURE STATEMENT}

The costs of publication of this article were defrayed in part by the payment of page charges. Therefore, and solely to indicate this fact, this article is hereby marked "advertisement" in accordance with 18 USC section 1734.

\section{ACKNOWLEDGMENT}

This work was supported in part by the Novartis Foundation, the Swiss National Science Foundation (PASMP3123269), an Oncosuisse grant (no. OCS-02259-08), a proportion of funding from the Department of Health's NIHR Biomedical Research Centre's funding scheme, and from the King's College London and UCL Comprehensive Cancer Imaging Centre CR-U.K. and EPSRC, in association with the MRC and DoH (England). No other potential conflict of interest relevant to this article was reported.

\section{REFERENCES}

1. Grant CS. Insulinoma. Best Pract Res Clin Gastroenterol. 2005;19:783-798.

2. Service FJ, McMahon MM, O'Brien PC, Ballard DJ. Functioning insulinoma: incidence, recurrence, and long-term survival of patients-a 60-year study. Mayo Clin Proc. 1991;66:711-719.

3. Hirshberg B, Livi A, Bartlett DL, et al. Forty-eight-hour fast: the diagnostic test for insulinoma. J Clin Endocrinol Metab. 2000;85:3222-3226.
4. Lepage C, Ciccolallo L, De Angelis R, et al. European disparities in malignant digestive endocrine tumours survival. J Cancer. 2010;126:2928-2934.

5. Grama D, Eriksson B, Martensson H, et al. Clinical characteristics, treatment and survival in patients with pancreatic tumors causing hormonal syndromes. World $J$ Surg. 1992;16:632-639.

6. Ramage JK, Davies AH, Ardill J, et al. Guidelines for the management of gastroenteropancreatic neuroendocrine (including carcinoid) tumours. Gut. 2005; 54(suppl 4):iv1-iv16.

7. Norton JA. Surgery for primary pancreatic neuroendocrine tumors. J Gastrointest Surg. 2006;10:327-331.

8. Reubi JC, Waser B. Concomitant expression of several peptide receptors in neuroendocrine tumours: molecular basis for in vivo multireceptor tumour targeting. Eur J Nucl Med Mol Imaging. 2003;30:781-793.

9. Gotthardt M, Lalyko G, van Eerd-Vismale J, et al. A new technique for in vivo imaging of specific GLP-1 binding sites: first results in small rodents. Regul Pept. 2006;137:162-167.

10. Wild D, Behe M, Wicki A, et al. [Lys ${ }^{40}\left(\right.$ Ahx-DTPA- $\left.{ }^{111} \mathrm{In}\right) \mathrm{NH}_{2}$ ] exendin-4, a very promising ligand for glucagon-like peptide-1 (GLP-1) receptor targeting. J Nucl Med. 2006;47:2025-2033.

11. Wild D, Macke H, Christ E, Gloor B, Reubi JC. Glucagon-like peptide 1-receptor scans to localize occult insulinomas. N Engl J Med. 2008;359:766-768.

12. Christ E, Wild D, Forrer F, et al. Glucagon-like peptide-1 receptor imaging for localization of insulinomas. J Clin Endocrinol Metab. 2009;94:43984405

13. Wild D, Theodoraki A, Kurzawinski TR, et al. 'Running on empty'. Eur J Nucl Med Mol Imaging. 2010;37:1439-1440.

14. Wicki A, Wild D, Storch D, et al. [Lys ${ }^{40}\left(\right.$ Ahx-DTPA- $\left.{ }^{111 \text { In }}\right) \mathrm{NH}_{2}$ ]-exendin-4 is a highly efficient radiotherapeutic for glucagon-like peptide-1 receptor-targeted therapy for insulinoma. Clin Cancer Res. 2007;13:3696-3705.

15. Kwekkeboom DJ, de Herder WW, Kam BL, et al. Treatment with the radiolabeled somatostatin analog $\left[{ }^{177} \mathrm{Lu}-\mathrm{DOTA}{ }^{0}, \mathrm{Tyr}^{3}\right]$ octreotate: toxicity, efficacy, and survival. J Clin Oncol. 2008;26:2124-2130.

16. Waldherr C, Pless M, Maecke HR, Haldemann A, Mueller-Brand J. The clinical value of ${ }^{90}$ Y-DOTA]-D-Phe ${ }^{1}-$ Tyr $^{3}$-octreotide $\left({ }^{90}\right.$ Y-DOTATOC) in the treatment of neuroendocrine tumours: a clinical phase II study. Ann Oncol. 2001;12:941945.

17. Korner M, Stockli M, Waser B, Reubi JC. GLP-1 receptor expression in human tumors and human normal tissues: potential for in vivo targeting. J Nucl Med. 2007;48:736-743.

18. Reubi JC, Waser B, Schaer JC, Laissue JA. Somatostatin receptor sst1-sst5 expression in normal and neoplastic human tissues using receptor autoradiography with subtype-selective ligands. Eur J Nucl Med. 2001;28:836-846.

19. Shastry M, Kayani I, Wild D, et al. Distribution pattern of ${ }^{68} \mathrm{Ga}$-DOTATATE in disease-free patients. Nucl Med Commun. 2010;31:1025-1032.

20. Zimmer T, Stolzel U, Bader M, et al. Endoscopic ultrasonography and somatostatin receptor scintigraphy in the preoperative localisation of insulinomas and gastrinomas. Gut. 1996;39:562-568. 